\title{
POLÍTICA CRIMINAL Y DOGMÁTICA JURÍDICO-PENAL EN LA REPÚBLICA DE WEIMAR
}

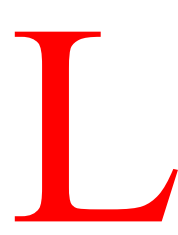

a República de Weimar tuvo una doble repercusión en el Derecho penal de su tiempo. Por un lado, llevó a cabo una revisión del Derecho penal anterior a la Primera Guerra Mundial, modificando en profundidad la pena de multa, creando un Derecho penal especial para jóvenes delincuentes, reformando el sistema penitenciario e introduciendo la cancelación de antecedentes penales para conseguir la rehabilitación del delincuente ${ }^{1}$. Muy importantes fueron también los trabajos en pro de una reforma total del Derecho penal, que cuajaron en una serie de proyectos de Código penal: el de 1919, que no era más que una reelaboración del de 1913; el de 1922, obra del entonces ministro de Justicia Gustav Radbruch, que acogía los postulados de la Escuela Moderna de von Liszt; el de 1925, el de 1927 y el de 1930, este último elaborado por una comisión parlamentaria bajo la presidencia de otro penalista, W. Kahl ${ }^{2}$. Ninguno de ellos llegó a convertirse en Código penal, aunque sí influyeron en reformas posteriores y alguno de ellos, como el de Radbruch de 1922, constituyera la base de los movimientos progresistas de reforma penal en Alemania que cuajaron en el Proyecto Alternativo de $1966^{3}$.

${ }^{1}$ Sobre las reformas penales habidas durante la República de Weimar informa cualquier Manual o Tratado de Derecho penal alemán: véase, por ejemplo, entre los traducidos al castellano, Jescheck, Tratado de Derecho penal, traducción de Mir Puig y Muñoz Conde, Barcelona, 1982, vol. 1, pág. 138; y entre los más recientes, Roxin, Strafrecht, 1992. pág. 58.

${ }^{2}$ Sobre los Proyectos de Código penal habidos en la República de Weimar, véase, además de la exposición resumida de los Tratados de Jescheck y Roxin citados en la nota 1, especialmente el trabajo dactilografiado de Lieselotte Jelowick, Zur Geschichte der Strafrechtsreform in der Weimarer Republik, Halle (Saale) 1983, quien, desde la perspectiva de la entonces República Democrática Alemana, ofrece una visión bastante crítica y negativa de estos Proyectos.

${ }^{3}$ En este sentido, vease, por ejemplo, los trabajos de Arthur Kaufmann y Jürgen Baumann, en Gedächtnisschrift für Gustav Radbruch, Göttingen, 1968. 
Por otro lado, la Ciencia alemana del Derecho penal alcanzó en aquella época su punto álgido, elevando a las más altas cotas de elaboración intelectual la estructura dogmática de la teoría del delito, cuyas bases habían sentado ya a principios de siglo Von Liszt y Beling ${ }^{4}$. Nombres como los de Radbruch, M. E. Mayer, o Mezger, aplicando una metodología propia de las ciencias del espíritu, en la línea marcada ya por la Escuela sudoccidental alemana del neokantismo (Windelband, Stammler, Rickert y Lask), elaboraron un sistema de la teoría del delito en el que cada una de sus categorías básicas (tipicidad, antijuridicidad y culpabilidad) se referían a valores específicos derivados de los fines del Derecho penal, que el penalista tenía que comprender, y no simplemente observar o describir $^{5}$. El neokantismo, en un intento de superación del concepto positivista de ciencia, trató de fundamentar el carácter científico de la actividad jurídica, distinguiendo entre ciencias de la naturaleza y ciencias del espíritu. Tanto unas como otras, decían los neokantianos, son auténticas ciencias porque tienen un objeto determinado y un método para investigarlo que les es propio, pero precisamente por eso difieren entre sí. Las ciencias de la naturaleza estudian su objeto desde el punto de vista causal explicativo, y las ciencias del espíritu estudian el suyo empleando un método comprensivo referido al valor. La Ciencia del Derecho se incluye entre estas últimas, porque, en sus esfuerzos por conocer el Derecho positivo, objeto de su investigación, tiene que acudir a una valoración?

La influencia de esta corriente filosófica en la Ciencia alemana del Derecho penal de la época de la República de Weimar fue considerable

${ }^{4}$ Constituyendo el llamado sistema clásico de la teoría del delito (así. por ejemplo, Jescheck, Tratado cit. nota 1, pág. 274). Una exposición de la evolución de la teoría del delito, a partir de ese momento, se encuentra en cualquier Manual o Tratado de Derecho penal alemán o español; un resumen de la misma y mi propia exposición al respecto en: Muñoz Conde, Introducción al Derecho penal, Barcelona, 1975, pág. 168 y ss.; también Muñoz Conde/García Arán, Derecho penal. Parte General, Valencia, 1993, págs. 191 y ss.

${ }^{5}$ Véase bibliografía citada en nota anterior e infra, notas 44 a 48.

${ }^{6}$ La distinción se encuentra en Dilthey y es acogida en la filosofía por Rickert, Ciencia cultural y ciencia natural, traducción de García Morente y prólogo de Ortega y Gasset, 2. ${ }^{a}$ ed. 1945, págs. 23 y ss.

${ }^{7}$ El transplante del neokantismo a la ciencia del Derecho lo hizo, según Larenz (Metodología de la Ciencia del Derecho, traducción de Gimbernat Ordeig, Barcelona, 1965, pág. 112), Emil Lask. También Gustav Radbruch puede incluirse en esta dirección metodológica (véase por ejemplo su Filosofía del Derecho, traducción de Medina Echevarría, Madrid, 1933, y su Introducción a la Filosofia del Derecho, traducción de Wenceslao Roces, $4 .^{\text {a }}$ ed., Méjico, 1974). Para una exposición de conjunto del pensamiento de este autor, aparte de los trabajos recogidos en el citado en nota 3, véase Baratta, «Relativismus und Naturrecht im Denken Gustav Radbruclis», en ArchRSPh, 1959, 505. Sobre la influencia del neokantisino en la Ciencia del Derecho penal alemán, véase Baratta, Positivismo e scienza del diritto penale, Milán, 1966; Muñoz Conde, Introducción cit., págs. 112 y ss. 
y supuso un impacto muy beneficioso, al dividir el estudio del delito en dos vertientes distintas con el mismo rango científico: la causal-explicativa (criminológica), por un lado, y la comprensiva-axiológica (dogmática), por otro. La Criminología y la Dogmática quedaban así perfectamente delimitadas, sin supeditarse la una a la otra, manteniendo cada una su importancia y su autonomía. El penalista, liberado del positivismo criminológico que por un momento había amenazado la propia existencia de la elaboración jurídico-dogmática del Derecho penal, podía dedicar sus afanes a la Dogmática jurídico-penal y dentro de ella al perfeccionamiento del sistema de la teoría del delito, verdadero banco de pruebas de todas las elucubraciones en torno a la esencia y fines del Derecho penal. La Criminología, en cambio, quedaba en manos de científicos naturalistas que estudiaban los mismos problemas que los juristas desde puntos de vista y con metodologías diferentes, sociológicas, biopsicológicas, etc. ${ }^{8}$

Pero esta clarificación conceptual, por otra parte tan necesaria, supuso, al mismo tiempo, una separación radical entre ambas formas de considerar los problemas penales. De ahora en adelante, Criminología y Dogmática jurídico-penal van a marchar cada una por su lado, sin relación entre sí, como dos mundos distintos, hablando incluso distintos idiomas. La separación entre el ser y el valor, entre las esferas ontológica y axiológica, condujo paradójicamente a la Ciencia alemana del Derecho penal en la época de la República de Weimar a una esquizofrenia científica que repercutió luego en la actitud que muchos de los penalistas de la época adoptaron frente al régimen nacionalsocialista, al que no sólo miraron con simpatía, sino también abiertamente apoyaron con sus teorías y elucubraciones dogmáticas. Un ejemplo representativo de esta actitud puede ser el caso de Edmundo Mezger, Catedrático de Derecho penal de la Universidad de Munich, cuyo Tratado de Derecho penal (1. a ed. 1930) es una de las obras más acabadas de la Dogmática jurídico-penal de aquella época, acogiendo los postulados teóricos y filosóficos del neokantismo y de las más puras esencias de la Ciencia jurídica tradicional alemana, y que, sin embargo, posteriormente, en la época nazi no tuvo empacho, no sólo en colaborar con la reforma penal puesta en marcha por el régimen nacional socialista, sino en dar cobertura pretendidamente científica a leyes represivas de carácter racista y a todo un sistema basado en la superioridad de la raza ada y la pureza de la sangre ${ }^{9}$. Pero ésta no fue sólo una característica

${ }^{8}$ Sobre esta concepción dualista de la Ciencia del Derecho penal, véase Muñoz Conde, Introducción cit.. págs. 101 y ss.

${ }^{9}$ Cfr., por ejemplo, su Kriminalpolitik und ihre kriminologischen Grundlagen, 1934 (hay traducción española de Rodríguez Muñoz, con el título de Criminología, 1942). 
de algunos penalistas ya importantes en la época de la República de Weimar, sino también de algunos más jóvenes que comenzaron a destacar ya en pleno período nazi, aunque su formación jurídica y filosófica tuvieran su origen en la etapa anterior. Valga de cita el caso de Hans Welzel, el creador de la teoría final de la acción, que sin haber incidido directamente, como Mezger, en la configuración del Derecho penal nacionalsocialista, desarrolló ya en aquella época una concepción teórica del sistema del Derecho penal mucho más afín a la ideología nazi que la del propio Mezger ${ }^{10}$.

Naturalmente hubo también penalistas en la época de la República de Weimar que no sólo no cooperaron posteriormente con el régimen nazi, sino que se opusieron abiertamente a él, hasta el punto de ser perseguidos o tener que abandonar el país. Valga de ejemplo el caso de Gustav Radbruch, el antiguo ministro de Justicia y autor del Proyecto de 1922, que fue expulsado de su cátedra de Derecho penal en la Universidad de Heidelberg por las autoridades académicas del régimen nazi. Sin embargo, y curiosamente, la influencia de las ideas de Radbruch, igual que las de otro gran penalista y filósofo del Derecho, M. E. Mayer, no fue tan importante en el Derecho penal como en la Filosofía del Derecho, mientras que la de los otros dos penalistas citados anteriormente, Mezger y Welzel, no sólo fue y es importante en la Dogmática jurídico-penal alemana, sino en la de otros muchos países, como es el caso de España, en donde ya incluso antes de la Guerra Civil (1936-39) se produjo una recepción de las elucubraciones dogmáticas producidas en Alemania en los años veinte.

Ya en 1931, Luis Jiménez de Asúa, catedrático de Derecho penal en la Universidad de Madrid y uno de los penalistas mejor informados en su época de todas las tendencias y corrientes metodológicas del Derecho penal, pronunció su lección inaugural del curso 1931-32 sobre la «Teoría jurídica del Delito», en la que se hacía eco de las más recientes aportaciones de la Dogmática jurídico-penal alemana, proponiendo un sistema y una metodología para el estudio de la teoría del delito muy similar a los dominantes en ese momento en Alemania ${ }^{11}$. Hasta tal punto quedó impresionado por las aportaciones

${ }^{10}$ Véase, por ejemplo, Frommel, Los orígenes ideológicos de la teoría final de la acción, traducción de Muñoz Conde, ADP, 1989; también Winfried Hassemer, La Ciencia jurídico penal en la República Federal de Alemania, traducción de Hormazábal Malarée, ADP 1993, pág. 44.

${ }^{11}$ Véase Jiménez de Asúa, Teoría jurídica del delito, 1931. Precisamente sobre estas bases redactó años después su monumental e incompleto Tratado de Derecho penal, siete volúmenes que han alcanzado diversas ediciones, apareciendo en Buenos Aires durante el exilio del citado autor en Argentina, entre 1950 y 1970. 
de la Dogmática alemana del Derecho penal de la época que mandó a diversos discípulos suyos a estudiar temas como la tipicidad (Ballvé) o la antijuridicidad (Guallart) a Alemania, e hizo que otro discípulo, el más destacado, José Arturo Rodríguez Muñoz, tradujera en 1935 la segunda edición del Tratado de Mezger de 1933, a la que además añadió valiosas notas que pueden considerarse como el inicio de la Dogmática jurídico-penal en España ${ }^{12}$. Es curioso y digno de mencionarse que Jiménez de Asúa asumiera con tanto entusiasmo esta nueva orientación, que después desarrollaría y ampliaría en los diversos volúmenes de su monumental Tratado que publicó en el exilio, ya que, aunque formado en Alemania en el seminario de Derecho penal que dirigía en Berlín a principios de siglo Franz von Liszt, cuyo Tratado de Derecho penal también vertió al español ${ }^{13}$, se había inclinado más hasta ese momento por la orientación sociológica y político-criminal del maestro berlinés e incluso por el positivismo sociológico de Ferri en Italia, que por la Dogmática jurídica. Y ello es tanto más destacable, cuanto Jiménez de Asúa era miembro importante del Partido Socialista Obrero Español y fue uno de los penalistas más influyentes en la reforma penal de la $2^{\mathrm{a}}$ República española, de cuya Constitución, inspirada en gran parte en la de la República de Weimar, fue uno de sus principales redactores. Parece, pues, paradójico que acogiera con tanto entusiasmo un planteamiento jurídico más bien conservador o propugnado por juristas claramente conservadores. Pero igual que decíamos antes respecto a Radbruch, la orientación dogmática común con muchos juristas conservadores no le impedía mantener su coherencia ideológica que, igual que en el caso del filósofo alemán, le llevó al exilio, donde murió treinta y dos años más tarde sin haber podido regresar nunca más a su patria ${ }^{14}$.

Mientras tanto, la Dogmática jurídico-penal, de la mano de la traducción del Tratado de Mezger y de los discípulos de Jiménez de Asúa, Rodríguez Muñoz y Juan del Rosal, floreció en la España de la posguerra, consolidando una teoría del delito de corte causalista, en la que se inspiró el Tratado de Antón Oneca ${ }^{15}$, y en cierto modo

12 Véase Mezger, Tratado de Derecho penal, traducción y notas de Rodríguez Muñoz, dos volúmenes, 1. ${ }^{\text {a }}$ ed., 1935.

${ }^{13}$ Véase Von Liszt, Tratado de derecho penal, traducción de Quintiliano Saldaña y Jiménez de Asúa, tres volúmenes, Madrid.

${ }^{14}$ Para una valoración global de la obra de Jiménez de Asúa, véase las diversas contribuciones contenidas en el homenaje que se le tributó en 1985 en la Universidad Complutense (publicado en Revista de la Facultad de Derecho de la Universidad Complutense, número monográfico 11, 1986).

${ }^{15}$ Antón Oneca, Derecho Penal, 2. a ed., Madrid, 1986 (1. ${ }^{\mathrm{a}}$ ed. 1949). 
los de Cuello Calón ${ }^{16}$, Del Rosal ${ }^{17}$ y Rodríguez Devesa ${ }^{18}$, que dominaron el panorama jurídico-penal español en los años 50 y 60. Sólo a partir de los años 60, con la traducción del Tratado de Maurach por Córdoba Roda ${ }^{19}$ y del Nuevo sistema del Derecho penal de Welzel por Cerezo $\mathrm{Mir}^{20}$, se va introduciendo en la dogmática jurídico-penal española el sistema de la teoría final de la acción y la polémica entre los partidarios de ésta y los de la tradicional concepción causal de la acción de E. Mezger, reproduciendo en España una polémica que había surgido en Alemania tras la Segunda Guerra Mundial y que había servido, aparte de sus indudables repercusiones en el perfeccionamiento del sistema de la teoría del delito, de pretexto para marginar, consciente o inconscientemente, los grandes problemas político-criminales que se habían puesto de relieve con la reforma penal inconclusa de la República de Weimar.

No fue hasta los años 70, y coincidiendo con el final de la larga dictadura franquista, cuando en la Ciencia penal española volvieron a plantearse cuestiones que ya se habían planteado en la República de Weimar y que incluso en Alemania habían quedado pospuestas hasta mediados de los años 60, por razones ideológicas evidentes. E igual que en el Romance del Cid, se puede decir que el espíritu liberal y democrático que, en sus orígenes, tuvo la República de Weimar ha ganado sus mejores batallas, tanto en Alemania como en España, mucho después de la desaparición de dicho régimen político, demostrando que las ideas básicas que inspiraron sus proyectos de reforma del Derecho penal siguen vigentes y, en cierto modo, muchas de ellas todavía sin realizar ${ }^{21}$.

\footnotetext{
${ }^{16}$ Cuelo Calón, Derecho penal, Parte General, varias ediciones que van desde la primera de 1926, hasta la $18^{\mathrm{a}}$ de 1980 (también es autor de una parte especial, que llegó hasta la 14ª ed. en 1975).

${ }^{17}$ Del Rosal, discípulo directo de Jiménez de Asúa, estudió en los años 30 en Alemania, publicando después de la Guerra Civil varias obras generales, entre las que destaca su Tratado de derecho penal, vol. 1 (1968), vol. 2 (1973).

${ }^{18}$ Rodríguez Devesa, Derecho Penal Español, Parte General, 1.a ed. 1969 (hay 16. ${ }^{\text {a }}$ ed., puesta al día por Serrano Gómez). También es autor de una Parte Especial (1. ed. en un solo volumen, 1965; hay 16. ${ }^{\mathrm{a}}$ ed., 1993. puesta al día por Serrano Gómez).

${ }_{19}$ Maurach, Tratado de derecho penal, traducción y notas de Córdoba Roda, dos volúmenes, Barcelona, 1962.

${ }^{20}$ Welzel, Un nuevo sistema del derecho penal, traducción y notas de Cerezo Mir, Madrid, 1966.

${ }^{21}$ En España estas propuestas (eliminación de las penas privativas de libertad de corta duración, configuración de la multa conforme al sistema de las cuotas-multa, introducción del sistema vicarial en la relación entre penas y medidas, etc.) no empezaron a ser acogidas hasta el advenimiento del régimen democrático, a partir de la muerte del dictador General Franco (20 de noviembre de 1975), cuajando algunas de ellas ya en el Proyecto de Ley Orgánica de Código penal de 1980, y en los sucesi-
} 
Dentro de las muchas aportaciones que la Ciencia alemana del Derecho penal de la República de Weimar hizo a la Política criminal y a la Dogmática jurídico-penal, me voy a ocupar fundamentalmente del tratamiento de los delincuentes habituales y del concepto de culpabilidad, ya que los planteamientos que entonces se hicieron de estas cuestiones han influenciado en gran manera la evolución posterior de la Política criminal y la Dogmática jurídico-penal tanto en Alemania como en España, y porque, además, reflejan del modo más contundente las contradicciones del Derecho penal y del modelo democrático liberal burgués del Estado de Derecho que sirvió de base a la República de Weimar.

A) Una de las aportaciones más significativas de los Proyectos de Código penal habidos en la República de Weimar al Derecho penal posterior fue, sin duda, la regulación unitaria de las medidas de seguridad posdelictuales, entronizando un sistema dualista o de doble reacción sancionatoria; frente al autor del delito culpable la consecuencia principal es la pena; frente al autor del delito, culpable o inculpable, pero peligroso, la medida de seguridad, aplicada conjuntamente o como sustitutivo de la pena.

Con ello procura darse, a grosso modo, respuesta a los tres tipos de delincuentes en base a los cuales había cuarenta años antes diseñado Von Liszt su sistema de sanciones penales $^{22}$; la pena, simplemente intimidatoria o admonitoria para el delincuente ocasional; la medida de seguridad y corrección para el delincuente peligroso pero

vos: Propuesta de Anteproyecto de Código penal de 1983, Proyecto de Código penal de 1994. En Alemania la reforma penal de la posguerra no comenzó realmente hasta los años 60 , en los que el Proyecto oficial de 1962 fue seguido en 1966 por un Proyecto Alternativo de un grupo de Profesores de Derecho penal que en buena parte acogieron los postulados de Von Liszt y Gustav Radbruch.

${ }^{22}$ Véase Von Liszt, Der Zweckgedanke im Strafrecht, publicado originariamente en Zeitschrift für die gesamte Strafrechtswissenschaft, III, 1882, pág. 1 y ss. (recogido luego en sus Strafrechtliche Vorträge und Aufsätze, tomo I, Berlín 1905. págs. 126 y ss., reimpresión de 1970, que es por donde se cita). Hay traducción española de Enrique Aimone Gibson, con revisión técnica y prólogo de Manuel de Rivacoba, acompañada de un trabajo de Jiménez de Asúa sobre Von Liszt, aparecida en Valparaíso (Chile), 1984, con el título La idea de fin en el Derecho penal. Sobre la influencia de Von Liszt en la reforma penal alemana de los años sesenta y concretamente sobre el Proyecto Alternativo de 1966, véase el trabajo de Roxin, «Franz Von Liszt y la concepción político-criminal del Proyecto Alternativo», en Problemas básicos del Derecho penal, traducción de Luzón Peña, Madrid, 1976, págs. 37 y ss. (publicado originariamente en el número dedicado a Von Liszt en la Zeitschrift für die gesamte Strafrechtswissenschaft, 81 (1969), págs. 613 y ss.). De la extensa bibliografía existente sobre el pensamiento de Von Liszt, me remito especialmente al trabajo de Monika Frommel, Präventionsmodelle in der deutschen Strafzweck-Diskussion, Berlín, 1987, págs. 17 y ss. 
corregible; la complementación de la pena por la medida hasta convertirla en una especie de pena indeterminada para el delincuente peligroso incorregible.

Sin embargo, este sistema de medidas de seguridad que, con más o menos variantes, se acoge en los Proyectos de 1922, 1925, 1927 y 1930, no se convirtió en Derecho vigente hasta 1933, en pleno período nazi, con la Ley sobre el delincuente habitual de 29-11-1933, que lo introdujo en el Código penal. Es curioso que, cuando se habla de esta Ley, todo el mundo en Alemania procura destacar que su elaboración y los trabajos preparatorios a la misma se llevaron a cabo en el período anterior, es decir, en la República de Weimar. No se sabe muy bien si ello se debe a un intento de desactivar el abuso que de la misma se hizo en el período nazi o, sibilinamente, para indicar que muchas de las ideas que fructificaron en este período se habían incubado ya en la etapa anterior. Sea por una u otra razón, lo cierto es que, por ejemplo, en el Proyecto de Radbruch las medidas ocupaban ya un lugar importante (parágrafos 42 a 62) y, como destaca el propio Radbruch, no tanto para dar respuesta al necesario control de los inimputables o semiinimputables que, por sus anomalías mentales, requerían del ordenado tratamiento y aseguramiento de su peligrosidad, sino para dar respuesta a una de las preocupaciones que ya Von Liszt había señalado como una de las tareas político-criminales más urgentes de realizar: el control de los delincuentes habituales, por tendencia, reincidentes.

Conocidas son las duras palabras que tan ilustre penalista, calificado como «liberal de izquierdas $»^{23}$, maestro de Radbruch y de Jiménez de Asúa, dedicó a este tipo de delincuentes en su Programa de Marburgo de 1882:

«Tal como un miembro enfermo envenena todo el organismo, así el cáncer de los cada vez con mayor rapidez crecientes delincuentes habituales penetra en nuestra vida social (...). Se trata de un miembro, pero del más importante y peligroso, en esa cadena de fenómenos sociales patológicos que acostumbramos a llamar con el nombre global de proletariado. Mendigos y vagabundos, prostituidos de ambos sexos y alcohólicos, estafadores y gentes del mundo galante en el más amplio sentido de la palabra, degenerados psíquicos y físicos. Todos ellos forman un ejército de enemigos básicos del orden social, en el que los delincuentes habituales constituyen su Estado Mayor» ${ }^{24}$.

\footnotetext{
${ }^{23}$ La expresión es de Calvi, en el prólogo a la edición italiana de la obra de Von Liszt, citada en nota anterior (véase el prólogo de Rivacoba citado en nota anterior, págs. 12 y ss.

${ }^{24}$ Von Liszt, Straf. Vorträge citado en nota 22, I, pág. 167.
} 
Como solución penal para este tipo de delincuentes, Von Liszt propone:

«La prisión perpetua o, en su caso, de duración indeterminada, en campos de trabajo, en «servidumbre penal», con estricta obligación de trabajar y con el máximo aprovechamiento posible de la fuerza de trabajo; sin excluir como pena disciplinaria la pena de azotes, y con la consiguiente pérdida obligatoria y duradera de los derechos civiles y políticos, para marcar el carácter deshonroso de la pena. El aislamiento individual sólo operaría como sanción disciplinaria, en celda oscura y con estricto ayuno» ${ }^{25}$.

Naturalmente, con este tipo de sanciones penales, la pena de muerte es para Von Liszt innecesaria: «una vez que los incorregibles son inocuizados, la pena de muerte es superflua» ${ }^{26}$.

No menos duras fueron las palabras que dedicó a este problema el otro gran penalista alemán de finales del siglo XIX y principios del XX, Karl Binding. Sabido es que este autor no era partidario de la pena indeterminada que proponía Von Liszt para los delincuentes habituales. Como representante cualificado de un Derecho penal retribucionista, de una concepción de la pena desprovista de todo fin preventivo, rechazaba que ésta se rebajase al nivel de una simple medida de seguridad:

«La pena es otra cosa, algo y más noble -decía Binding-. Lo que hay que hacer es configurarla de un modo más contundente contra la «reincidencia criminal» y utilizarla como forma de inocuización de la «ralea» criminal, agravándola incluso, si hiciera falta, en caso de reincidencia hasta la prisión perpetua o la pena de muerte» ${ }^{27}$.

Como se ve, las diferencias entre ambos autores, que dieron lugar a la famosa «lucha de Escuelas», eran más nominalistas que de contenido. Lo que Von Liszt pretendía con su tipología de autores era la «inocuización» de los que consideraba incorregibles; lo que Binding defendía con su Derecho penal retributivo era exactamente lo mismo, pero exasperando la gravedad de la pena, basando la más contundente reacción penal (prisión perpetua o incluso la

${ }^{25}$ Von Liszt, ebenda, pág. 170.

${ }^{26}$ Von Liszt, ebenda, pág. 173.

${ }^{27}$ Binding, Prólogo a su Grundriss des Strafrechts, AT, 1906. Sobre Binding y la «lucha de escuelas», puede verse la obra de Frommel citada en nota 22, y Kögler, Die zeitliche Unbestimmheit der freiheitsentziehender Sanktionen des Strafrechts, Frankfurt am Main, 1988, pág. 38. 
pena de muerte) en una mayor culpabilidad del sujeto o en ideas abstractas de nobleza y exaltación del concepto de pena. Pero la finalidad última es en ambos autores la misma y, por lo demás, bastante clara.

Y si todo ello se había propuesto por los más cualificados penalistas del momento, en pleno período de expansionismo militar, económico y político del Segundo Imperio Alemán, con Bismarck a la cabeza, puede imaginarse lo que pensarían al respecto los penalistas y políticos reaccionarios o más conservadores cuarenta años después, tras la humillante derrota alemana de la Primera Guerra Mundial y el no menos humillante Tratado de Versalles, con un país arruinado, con millones de desempleados y con un aumento de la criminalidad hasta entonces inimaginable en la muy civilizada y disciplinada Alemania del Canciller de Hierro y del Emperador Guillermo II. Por eso, no es extraño que el propio Radbruch, miembro del Partido Socialdemocrático, ministro de Justicia en 1922 con el Canciller Wirth, se viera obligado a dar una respuesta que podemos calificar de ecléctica a este problema en su famoso Proyecto, en una línea que ya había sido más o menos claramente acogida en los Proyectos anteriores, siguiendo en esto la propuesta que había hecho el suizo Carl Stoos en su Anteproyecto de 1896, es decir, el famoso dualismo o sistema de doble vía. A este respecto dice Radbruch en la Fundamentación de su Proyecto ${ }^{28}$ :

«El Proyecto propone una contundente intervención contra la delincuencia habitual, aún mayor contra la profesional, que, como consecuencia de la guerra, ha adoptado las formas más amenazantes. Quien, por su repetida reincidencia, se convierte en un delincuente habitual peligroso para la seguridad pública, puede ser castigado en el Proyecto con severas penas de prisión que pueden llegar, en caso de delitos menos graves, a cinco años $\mathrm{y}$, en caso de delitos graves, hasta los quince años.

Aquí se prevé, por tanto, un marco penal especial contra una determinada clase de personas, sin consideración a la clase de delito; en la medición de la pena el hecho retrocede completamente ante el autor. Pero el Proyecto no se da por satisfecho con esta agravación, aunque limitada, de la pena, y posibilita que los delincuentes citados en el parágrafo 77 , que no son corregidos por la pena de prisión agravada, sean retenidos

${ }^{28}$ Entwurf eines Allgemeinen Deutschen Strafgesetzbuches (1922), publicado en 1952 con un prólogo de Thomas Dehler y una introducción de Eberhard Schmidt, pag. 57. 
para seguridad de la sociedad, una vez cumplida la pena, imponiendo un internamiento de seguridad por un tiempo no determinado en un principio (parágrafo 45).

El Proyecto no ha acogido, en cambio, la «sentencia indeterminada». Cuando se impone una pena, la duración de la misma debe determinarse ya en la sentencia. Pero la idea fundamental de la sentencia indeterminada, hacer depender la mayor o menor duración de la pena de prisión del efecto que tenga su ejecución en el condenado, encuentra, sin embargo, suficiente consideración en el Proyecto. El internamiento por tiempo indeterminado que el Proyecto rechaza para las penas encuentra, en cambio, amplia acogida en las medidas de seguridad».

Como bien dice Eberhard Schmidt, en la introducción al Proyecto de Radbruch que se publicó en $1952^{29}$, «la actitud fundamental de una ley sobre el sentido y misión de la pena, se deduce con especial claridad de la posición que adopte en la cuestión de la relación entre penas y medidas de seguridad. Especialmente relevante es la respuesta que la ley dé a la cuestión del delincuente habitual peligroso». Comprensible es, sin embargo, dice Schmidt, «que frente a este problema central de la Política criminal y la Dogmática jurídico-penal el ministro de Justicia, Radbruch, no podía sentirse tan libre como el intelectual Gustav Radbruch $»^{30}$, justificando así, de algún modo, la propuesta del proyecto Radbruch de combinar la agravación de la pena con la custodia de seguridad indeterminada para los delincuentes habituales. De todos modos, como el propio Schmidt advierte, el dualismo extremo a que este sistema conduce es atenuado por el parágrafo 48 del Proyecto que permite el intercambio vicarial entre la pena y la custodia de seguridad: «Si se impone la custodia de seguridad junto con la pena, el Tribunal puede ordenar que la custodia se cumpla en lugar de la pena. En tal caso, el condenado deber permanecer internado en el establecimiento el tiempo que hubiera durado la pena».

Este sistema que, como dice Schmidt, todavía determinó el Proyecto de 1925, fue abandonado en los Proyectos de 1927 y 1930, adoptándose en la definitiva ley de 1933 un estricto dualismo, «tras el cual se oculta la fatal palabrería nacionalsocialista de la función «expiacionista» de la pena, que no podía ser perjudicada por la función de seguridad de la custodia. Pero debe señalarse con toda claridad que el nacional socialismo pervirtió el sentido de la idea de

${ }^{29}$ Véase Introducción de Schmidt citada en nota anterior, pág. XXI.

${ }^{30}$ Schmidt, ebenda, pág. XXII. 
expiación, convirtiendo este concepto ético en pantalla de su terror penal» ${ }^{31}$.

Una buena prueba de todo ello es el uso que hizo el nacionalsocialismo de esta custodia de seguridad:

«Hasta 1939 se impuso la custodia de seguridad a más de 1.000 personas por término medio al año e incluso en 1938 hubo un día en el que se encontraban sometidas a esta medida casi 4.000 personas $\rangle^{32}$. Según Hellmer ${ }^{33}$, entre 1934 y 1942 fueron condenadas a este internamiento de seguridad más de 16.000 personas.

«Probablemente -dice Monika Frommel ${ }^{34}$ - fueron enviadas a campos de concentración, aunque hasta hoy apenas nadie se acuerde de los llamados «criminales» asesinados en esos campos de exterminio, ya que no se les considera víctimas del nacionalsocialismo, ni son identificados como grupo. Ello explica también que esta Ley contra delincuentes habituales no sea considerada ni siquiera hoy como un ejemplo característico de la política criminal nacionalsocialista».

Pero si se recuerdan las palabras de Von Liszt y Binding, se comprenderá por qué se ha dado esa impresión a las generaciones venideras: ciertamente, no hay tantas diferencias entre lo que estos autores decían respecto a los delincuentes habituales y la praxis penal que se llevó a cabo al hilo de estas ideas, treinta o cuarenta años más tarde, por la Justicia nacionalsocialista, sin que las preocupaciones y reservas adoptadas por Radbruch en su Proyecto sirvieran, en algún modo, de freno a la misma. Incluso todavía en los años treinta, la praxis penal nacionalsocialista recibió los refuerzos teóricos del representante del ala derecha de Von Liszt, Franz

${ }^{31}$ Schmidt, ebenda, pág, XXXIII, nota 44.

32 Jescheck, Tratado citado nota 1, pág. 1112, citando a Exner.

${ }^{33}$ Hellmer, Der Gewonheitsverbrecher und die Sicherungsverwahrung 1934-1935, Kiel, 1961. El director de este trabajo de investigación de Hellmer, el prestigioso penalista de Kiel Hellmuth Mayer, dice en su Strafrechtsreform für heute und morgen, 1962, pág. 163, nota 13: «No se puede saber ya cuál era el número de los condenados a internamiento de seguridad en 1945. Quizá fueran unos 15.000. Según el escrito de la defensa de los funcionarios ministeriales obligados a cooperar, aproximadamente unos 9.000 internados fueron entregados, de los que unos 8.000 podían haber muerto»».

${ }^{34}$ Frommel, «La lucha contra la delincuencia en el Nacionalsocialismo», traducción de Muñoz Conde, en Estudios penales y criminológicos, XVI, Santiago de Compostela, 1993, pág. 5 y ss. 
Exner $^{35}$, y del penalista conservador Edmund Mezger, quien con su teoría de la «culpabilidad por la conducción de vida» legitimó la agravación de pena para los reincidentes ${ }^{36}$, además del refuerzo policial que representó el «arresto policial» que se aplicaba por la Gestapo a los «enemigos del pueblo» ${ }^{37}$.

No es por eso extraño que un penalista español, también formado en el seminario berlinés de Von Liszt, pero igualmente influenciado por el positivismo criminológico de Ferri, Jiménez de Asúa, pudiera llegar a ser uno de los redactores de un engendro de Ley como fue la Ley de Vagos y Maleantes de 1933, que, además, como su propio nombre indica, permitía la aplicación de medidas predelictuales a peligrosos sociales, vagos, maleantes, prostitutas, etc., sin exigir la previa comisión de un delito ${ }^{38}$; lo que por cierto ya considero con cierta simpatía Radbruch en la Fundamentación de su Proyecto ${ }^{39}$. No hay que olvidar tampoco la situación política y económico-social de la España republicana de1933, pero no deja de ser un sarcasmo y una advertencia para el futuro que el principal uso de la Ley de Vagos y Maleantes la hiciera el régimen dictatorial de Franco que incluso llegó a «perfeccionarla» con la Ley de Peligrosidad y Rehabilitación social de 1970, aún formalmente vigente, mientras que Jiménez de Asúa abjuraba de la misma.

En este sentido, la obra reformadora penal de la República de Weimar, incluso en su vertiente más liberal y progresista en el Proyecto de Código penal de Radbruch, tiene en muchos aspectos el lado negativo del uso que de la misma hizo el nacionalsocialismo, que, como dice Richard Schmidt, «prometió el mantenimiento de lo

${ }^{35}$ Exner, Die Reichskriminalistik von 1934 und die Entwicklung der Kriminalität seit der Nationalen Revolution, MSchr. Krimbiol., 1938, pág. 336.

${ }^{36}$ Mezger, «Dic Straftat als Ganzes», en Zeitschrift für die gesamte Strafrechtwissenschaft, 57, 1938 , pág. 675 y ss.

${ }^{37}$ Véase Frommel, ob. citada en nota 34, pág. 52 y ss.

${ }^{38}$ Véase Jiménez de Asúa, «La Ley de Vagos y Maleantes, un ensayo legislativo de peligrosidad sin delito», en Revista General de legislación y Jurisprudencia, 1933. Este ley fue sustituida, en plena dictadura franquista, por la Ley de Peligrosidad y Rehabilitación social de 1970, justamente criticada por la doctrina española desde su promulgación, y que aún no ha sido derogada formalmente (véase Muñoz Conde, Las medidas de seguridad, eficacia y ámbito de aplicación, en La Ley, 1991).

${ }^{39}$ En Entwurf citado en nota 28, pág. 59, atribuyendo a las medidas de seguridad una naturaleza más afin al Derecho administrativo que al penal, tanto cuando son predelictuales, como cuando son posdelictuales. En este sentido. ya se pronunció Octker, fundador de la Asociación Alemana de Derecho penal, quien proponía una estricta separación entre penas y medidas de seguridad, excluyendo éstas del Código penal para regularlas separadamente en un Código de seguridad (véase Octker, «Die deutsche strafrechtliche Gesellschaft», en Der Gerichtsaal, tomo 91, 1925. págs. 321 y ss.). 
existente, el fortalecimiento del poder estatal y el rechazo del 'sentimentalismo humanitario'» ${ }^{40}$.

No es, por eso, extraño que algún autor, como Jellowik, diga que la Política criminal del nacionalsocialismo no supuso realmente una ruptura, sino una continuación de la Política criminal planeada por la burguesía conservadora que finalmente ostentaba el poder en la última etapa de la República de Weimar ${ }^{41}$. Aunque esta afirmación puede parecer exagerada, en todo caso, no cabe duda de que al nacional socialismo le venía muy bien para llevar a cabo su particular Política criminal la fundamentación conservadora y autoritaria que desde los tiempos de Von Liszt se había mantenido como un hilo conductor en los Proyectos de la República de Weimar en relación con el tratamiento de los delincuentes habituales ${ }^{42}$. Curiosamente, fue ésta la primera y casi única reforma penal importante que acometió el nuevo régimen, pareciendo como que, una vez introducida la custodia de seguridad por tiempo indeterminado en el sistema de las sanciones penales, ya no eran urgentes otras reformas que, a buen seguro, auspiciadas por las nuevas tendencias del Derecho penal de autor, hubieran seguido una línea muy similar

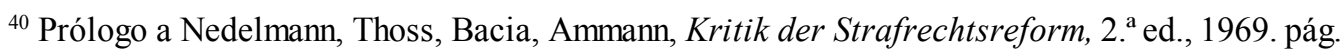
9.

${ }^{41}$ Jelowik, ob. citada en nota 2, pág. 43. La tesis de que el nacional socialismo representó una «ruptura» y no una mera modificación de la situaciónjurídica anterior (mantenida por ejemplo por Eb. Schmidt, Einführung die Geschichte der deutschen Strafrechtpflege, $3 .^{a}$ ed., pág. 425 y ss.), no es, situada en un contexto político más amplio, tan clara como a primera vista pudiera parecer. Ciertamente, el nacionalsocialismo eliminó todos los obstáculos jurídicos que pudieran oponerse a su política criminal (la admisión de la analogía como fuente del derecho penal es una prueba de ello), prescindiendo completamente de los elementos característicos del Estado de Derecho que sí se mantenían, al menos formalmente, en los Proyectos de la república de Weimar; pero el espíritu conservador autoritario e incluso reaccionario que animaba a muchos de los penalistas de los años 20 encontró rápido acomodo en el período nacional socialista. Así, por ejemplo, formaron parte de la comisión de reforma del Derecho penal nombrada por el Gobierno nacionalsocialista penalistas tan prestigiosos como Mezger, Nagler o Kohlrausch. Y la Asociación alemana de jueces, que durante toda la República de Weimar había hecho gala de su «apoliticismo», saludaba el 19 de marzo de 1933, en nombre de sus 13.000 miembros, al régimen hitleriano, asegurándole que gozaba de su entera confianza (cita tomada de Kühl, La República de Weimar, Valencia, 1991, pág. 95). En general, casi todas las instituciones públicas acogieron la venida del régimen nazi con grandes muestras de simpatía y adhesión. Después de todo, el nacionalsocialismo no llegó al poder, como otros fascismos, tras un «golpe de Estado», o fuera de los cauces previstos en la Constitución de Weimar, sino por la propia «autodisolución» de la República de Weimar, cuyos dirigentes en ese momento entregaron el poder a Hitler sin ningún problema (véase Kühl, ob. a. cit., pág. 322 y ss.).

${ }^{42}$ En este sentido, Frommel, ob. citada en nota 34, pág. 47 y ss.
} 
a la ya iniciada con la reforma de 28 de noviembre de 1933. En este sentido, la reforma penal nacionalsocialista fue, por lo menos en sus orígenes, la culminación de la ideología antiliberal y autoritaria que caracterizó a buena parte de los penalistas, jueces y profesores universitarios más importantes en el período de la República de Weimar ${ }^{43}$.

B) El contrapeso a este Derecho penal eminentemente represivo que ya el propio Von Liszt había preconizado contra los «enemigos fundamentales del orden social», fue el concepto de culpabilidad, que precisamente recibió su formulación más acabada y profunda de los principales penalistas del período de la República de Weimar.

Ciertamente, fue ésta una época en la que floreció la Dogmática jurídico-penal, revitalizada por el influjo del neokantismo de la Escuela sudoccidental alemana. Las categorías formales ya elaboradas anteriormente de la tipicidad, la antijuridicidad y la culpabilidad fueron rellenadas con contenidos valorativos, dando lugar a lo que se ha dado en llamar la teoría neoclásica del delito $^{44}$, en la que a partir del concepto de acción, entendida en su función puramente causal, se iban añadiendo las distintas categorías, cada una con una función y contenido propios. La tajante separación entre lo objetivo (antijuridicidad) y lo subjetivo (culpabilidad) queda atenuada con el descubrimiento de los llamados elementos subjetivos del injusto ${ }^{45}$. La tipicidad pasa de ser una categoría puramente formal, plasmadora del principio de legalidad en la pura descripción del suceso delictivo externo, a constituir un indicio de la antijuridicidad o incluso su propia esencia ${ }^{46}$. Y la antijuridicidad, entendida anteriormente como simple infracción de la norma jurídica, se llena de contenido con el concepto de bien jurídico, cuya lesión o puesta en peligro constituye

\footnotetext{
${ }^{43}$ Véase Marxen, Der Kampf gegen das liberale Strafrecht, 1975. Un ejemplo característico de las nuevas tendencias autoritarias que irrumpieron en el Derecho penal de aquella época es el libro de Dahm/Schaffstein, Liberales oder autoritäres Strafrecht, 1933.

${ }^{44}$ La denominación se encuentra en Jescheck, Tratado citado nota 1, pág. 276 y ss.; también en Roxin, Strafrecht cit. nota 1, pág. 110.

${ }^{45} \mathrm{La}$ existencia de elementos subjetivos en el injusto concebido objetivamente fue constatada ya en 1911 por Fischer y en 1915 por Hegler, pero fue Mezger, «Die subjektiven Unrechtselemente», en Gereichtssaal, 89, 1924, págs. 207 y ss., quien más profundizó en la elaboración teórica de tales elementos.

${ }^{46}$ Mientras que en Beling, Die Lehre vom Verbrechen, 1906, pág. 23 y ss., la tipicidad no tenía ningún significado valorativo, en M. E. Mayer, Der Allgemeine Teil des Deutschen Strafrechts, 1992, pág. 10 , nota 22, era ya un indicio de la antijuridicidad, y en Mezger, Tratado citado nota 12, tomo 1, págs. 375 y ss., la «ratio essendi» de la antijuridicidad (el delito, para él, es la acción típicamente antijurídica).
} 
su esencial ${ }^{47}$, dando lugar a una nueva visión de las causas de justificación ${ }^{48}$.

Pero es el concepto de culpabilidad, ya previamente elaborado a finales del siglo XIX por los neohegelianos y por Von Liszt, Binding y Merkel, el que recibe un impulso mayor y una configuración más acorde con las tendencias que caracterizaron a la Dogmática jurídico-penal en la República de Weimar ${ }^{49}$.

Todavía a comienzos de los años 20 dominaba en la Dogmática jurídico-penal alemana un «concepto psicológico» de culpabilidad que reducía ésta a la simple relación psicológica entre el autor imputable y el hecho por él realizado. Si esta relación era intencional, la culpabilidad era dolosa; si sólo era una relación imprudente, la culpabilidad, menos grave, era culposa. Dolo y culpa eran, pues, dos especies de culpabilidad (Schuldarten) basadas en la previa normalidad psíquica del autor del delito (imputabilidad) ${ }^{50}$.

Sistemáticamente, esta concepción de la culpabilidad era una consecuencia de la estricta separación entre el aspecto objetivo y el subjetivo del delito, que constituía la base del sistema clásico de la teoría del delito. Así, mientras todo lo objetivo se incluía en el injusto, es decir, en la tipicidad y la antijuridicidad, lo subjetivo, es decir, la relación psicológica del autor con su hecho más la imputabilidad del autor como presupuesto, se incluía en la culpabilidad.

Ello fue también consecuencia del pensamiento naturalista de finales del siglo XIX, que reducía el ámbito de la Psicología a los fenómenos psíquicos mensurables y puramente descriptivos, excluyendo cualquier tipo de valoración de los mismos ${ }^{51}$.

De todo ello se deducía en Derecho penal una consecuencia dogmática ineludible: la exclusión de la responsabilidad por el resultado o responsabilidad puramente objetiva, es

${ }^{47} \mathrm{El}$ concepto de bien jurídico proviene ya de Birnbaum, quien lo formuló en 1835, pero ya Von Liszt, Tratado citado nota 13, tomo II, pág. 324, lo acogió como fundamento de su concepto de antijuridicidad material (lesión o puesta en peligro de bienes jurídicos), tesis ampliamente desarrollada por Graf zu Dohna, Hegler y Mezger (véase de este último: Tratado citado nota 12, tomo I, págs. 398 y ss.

${ }^{48}$ Véase Mezger, Tratado citado nota 12, tomo I, pág. 403 y ss. y 412, quien admite ya las «causas supralegales de justificación».

${ }^{49}$ Véase Achenbach, Historische und dogmatische Grundlagen der strafrechtssystematischen Schuldlehre, Berlín, 1974, pág. 133.

${ }^{50}$ Véase Von Liszt, Tratado citado en nota 13, vol. II, págs. 375 y ss.

${ }^{51}$ La psicología de la asociación de Herbert, Spencer y Tame pretendía, en efecto, una explicación puramente causal de la conducta, sin tratar de comprender los motivos; críticamente, Dilthey, «Ideen über eine beschreibende und ergliedernded Psichologie», en Gesammelte Schriften, tomo V: «Die geistige Welt», 2. ${ }^{a}$ ed., 1957, pág. 139. Sobre estos planteamientos psicológicos, véase mi libro: $E l$ desistimiento voluntario de consumar el delito, Barcelona, 1972, págs. 18 y ss. 
decir, erradicar del Derecho penal los vestigios del antiguo versari in re illicita, excluyendo la culpabilidad (o mejor, las formas de culpabilidad) cuando el resultado no era atribuible a una actuación dolosa o culposa de quien lo había causado. Fue precisamente Radbruch, uno de los máximos representantes del concepto psicológico de culpabilidad, quien llevó a cabo esta idea en su Proyecto de 1922, exigiendo en el parágrafo 15 que, en los delitos cualificados por el resultado, el resultado cualificante cuya producción determina una pena más grave sólo pueda ser imputado cuando haya sido causado al menos imprudentemente. Una exigencia que sólo se convirtió en Derecho vigente en Alemania con una reforma de 1953 (actual parágrafo 18 StGB), y en España, tras la reforma de 1983 (arts. 1 y 6 bis b del vigente Código penal).

Pero no es esta aportación, con ser fundamental, la que más caracteriza el concepto de culpabilidad desarrollado por la Dogmática jurídico-penal alemana en la época de la República de Weimar. Ya en 1907 había destacado Reinhard Frank que la culpabilidad es más que la imputabilidad y el dolo o la culpa, ya que en la valoración jurídica de la acción igualmente pueden ser relevantes las circunstancias concomitantes que, por ejemplo, explican por qué puede ser absuelto quien actúa en estado de necesidad, aunque sea imputable y sepa lo que hace, es decir, actúe con dolo. La culpabilidad, decía Frank, es más que eso; para declarar a alguien culpable por el hecho delictivo cometido es necesaria la «reprochabilidad» de la acción; sólo teniendo en cuenta estos tres elementos: imputabilidad, dolo o culpa y circunstancias concomitantes, puede formularse un juicio global de reproche al autor por lo que ha hecho ${ }^{52}$.

Esta conversión del concepto de culpabilidad en un juicio de reproche y, por tanto, en un concepto normativo, determinó la evolución posterior, ya en pleno apogeo de la Filosofía valorativa neokantiana en la Dogmática jurídico-penal de los años veinte, y abrió las puertas a una de las teorías más características de aquella época: la teoría de la no exigibilidad.

Fue Berthold Freudenthal quien en 1922 habló por primera vez de la no exigibilidad como el verdadero fundamento del concepto de culpabilidad: «Si ésta supone siempre una desaprobación que se hace al autor del delito por haberse comportado así, mientras que podía y debía hacerlo de otra manera, el hecho no podrá reprochársele cuando, teniendo en cuenta las circunstancias concomitantes en el caso concreto, no podía exigírsele un comportamiento distinto al que llevó a cabo» ${ }^{53}$.

${ }^{52}$ Véase Frank, Über den Aufbau des Schuldbegriffes, Giessen, 1907, pág. 4.

${ }^{53}$ Véase Freudenthal, Schuld und Vorwurf im geltenden Strafrecht, Tubinga, 1922. 
Tras esta teoría estaba la grave situación económica y social que tenían que soportar las masas trabajadoras en aquella época. El mismo Freudenthal no se recata de decir que con su teoría se podía absolver a gente como la comadrona que inscribía los niños nacidos en días de fiesta como nacidos en días laborales, para que sus padres, mineros de la Cuenca del Ruhr, tuvieran un día de asueto pagado; o el viajante de comercio que, ante la tacañería de la firma que representa, se ve obligado a quedarse con dinero para poder atender los gastos de viaje que realiza por cuenta de la misma y no perder el puesto de trabajo; o el de la joven siciliana que mata a su tío que la ha deshonrado para evitar que su marido se entere $^{54}$. Ya anteriormente el Reichsgericht (RGSt. 30, 25 ss.) había absuelto al cochero que, siguiendo las órdenes de su amo, para no perder el puesto de trabajo, enganchó en el carro a una yegua con tendencia a desbocarse, que, efectivamente, atropelló e hirió gravemente a un peatón.

La teoría de Freudenthal pronto fue criticada por los penalistas más conservadores ${ }^{55}$, que aludían al debilitamiento de la prevención general y a la inseguridad jurídica que producía. Pero fueron sobre todo los penalistas afines al nacionalsocialismo los que la rechazaron con especial contundencia, viendo en ella «un producto de la Ciencia liberal del derecho penal incompatible con la pretensión de disponibilidad total del Estado nacionalsocialista sobre todos sus ciudadanos» ${ }^{56}$ y un «quebrantamiento de los huesos del Derecho penal ${ }^{57}$. Sin embargo, en una versión más objetivizada y generalizadora de Goldschmidt y Eberhart Schmidt ${ }^{58}$ y convertida posteriormente en un principio regulativo general $^{59}$, la teoría de Freudenthal ha llegado hasta nuestros días y ocupa un puesto importante en la moderna concepción de la culpabilidad, tanto en Alemania como en España $^{60}$.

También el conocimiento de la antijuridicidad como elemento

\footnotetext{
${ }^{54}$ Freudenthal, ebenda, pág. 18 y ss.

${ }^{55}$ Véase sobre todo la recensión a la monografía de Freudenthal hecha por Liepmann, en Zeitschrift für die gesamte Strafrechtswissenschaft, 43, 1922, págs. 710-713. Además: Grosmann, Die Grenzen von Vorstatz und Fährlässigkeit, Hamburgo, 1924, págs. 8 y ss.; Schumacher, Um das Wesen der Strafrechtsschuld, 1927, págs. 69 y ss.; Hirschberg, Schuldbegriff und adäquate Kausalität, Breslau, 1928, pág. 18.

${ }_{56}$ Schaffstein, Die Nichtzumutbarkeit als allgemeiner übergesetzlicher Schuldausschliesungsgrund, Leipzig,1933, págs. 25 y ss.

${ }^{57}$ Reproche global que los penalistas afines al nacionalsocialismo hacían del Derecho penal liberal: véase Dahn/Schaffstein, ob. citada en nota 43. Sobre estas críticas, véase Achenbach, ob. citada en nota 49, págs. 155 y ss.

${ }^{58}$ Véase Achenbach, ob. citada en nota 43, págs. 145 y ss.

${ }^{59}$ Tesis de Henkel, en Mezger-Festschrift, 1954, págs. 260 y ss.

${ }^{60}$ En España, aunque fue originariamente rechazada por Rodríguez Muñoz en sus notas al Tratado de Mezger, citado en nota 12, tomo II, pág. 217, fue posteriormente acogida a partir de la monografía de Sainz Cantero, La exigibilidad de con-
} 
del dolo o de la culpabilidad y, por tanto, la relevancia del error de derecho, o en terminología más moderna error de prohibición, como causa de exención o de atenuación de la responsabilidad penal, puede considerarse hoy como una de las aportaciones características de la Dogmática jurídico-penal alemana de la República de Weimar. Frente a una jurisprudencia del Reichsgericht aferrada al principio «error iuris nocet» y que, por tanto, consideraba irrelevante el desconocimiento de la antijuridicidad, la doctrina alemana, sobre todo a partir de Binding ${ }^{61}$, mantenía que el conocimiento de la significación antijurídica de los hechos era también un elemento integrante del concepto de dolo, concediendo al error sobre la antijuridicidad la misma importancia que al error sobre los hechos, es decir, la exclusión de la imputación dolosa y la posibilidad de castigar, en su caso, por delito culposo, si el error se debía a culpa o negligencia del sujeto.

Frente a esta concepción doctrinal, que luego se llamaría «teoría del dolo» ${ }^{62}$, se fue elaborando en los años veinte otra teoría, «la de la culpabilidad», que consideraba también el conocimiento de la antijuridicidad como un elemento de la culpabilidad, pero dándole una significación autónoma y separada del dolo ${ }^{63}$. Para esta teoría de la

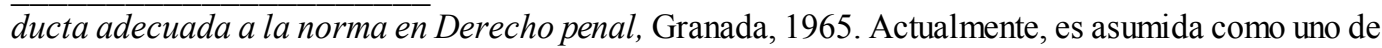
los elementos del concepto de culpabilidad; véase Muñoz Conde-García Arán, Derecho penal, Parte General, Valencia, 1933. págs. 350 y ss. También en Alemania, la doctrina dominante acoge la exigibilidad como elemento de la culpabilidad, si bien con matizaciones a la teoría originaria, y reservándola para algunos casos de delitos culposos y omisivos; así, por ejemplo, Jescheck, Tratado citado en nota 1, pág. 658; Roxin, ob. citada en nota 1, pág. 539. Más amplia acogida tiene en Jakobs, Strafrecht, AT, 2. ${ }^{a}$ ed., 1991, quien, sin embargo, se muestra escéptico respecto a la posibilidad de una cláusula general de inexigibilidad como causa de exculpación (pág. 590 ss.). También Achenbach, «Wiederbelebung der allgemeinen Nichtszumutbarkeitsklausel im Strafrecht?», en JR 1975, págs. 492 y ss., se muestra contrario a derivar directamente de la Constitución una «causa general de exculpación por inexigibilidad», rechazando la propuesta en este sentido de Lücke, Jr 1975, págs. 35 y ss. y Witting, JZ 1969, págs. 546 y ss. Sin embargo, el problema se vuelve a plantear en los casos de delincuentes por convicción, insumisos, manifestantes pacíficos, etc., que infringen leyes ampliamente cuestionadas en muchos sectores sociales; para más detalles, véase Muñoz Conde, «El delincuente por convicción en Derecho penal», Homenaje a Roxin, Barcelona, 1994 (inédito).

${ }^{61}$ Binding, Die Normen und ihre Übertretung, tomo II, reimpresión de la $2{ }^{a}{ }^{\text {ed. de Leipzig }}$ 1916, 1965, pág. 940, 955.

${ }^{62}$ En su versión estricta, defendida sobre todo por Binding, Nagler y originariamente por Mezger, sigue siendo defendida en Alemania por un sector minoritario, representado sobre todo por Schmidhäuser, Strafrecht, AT, 1. a ed., 1972, pág. 327. Véase también Schmidhäuser, «Über Aktualität und Potentialität des Unrechtsbewusstseins», en Festschrift für Hellmuth Mayer, 1966, págs. 331 y ss.; el mismo, «Unrechtsbewusstsein und Schuldgrundsatz», JZ 1975, págs. 1.087 y ss.; el mismo, «Der Verbotsirrtum und das Strafgesetz», JZ 1979, págs. 361 y ss.

${ }^{63}$ Ya en 1989 había destacado Adolf Merkel la posibilidad del conocimiento de la infracción del deber como un elemento autónomo de la culpabilidad (véase 
culpabilidad, el conocimiento de la antijuridicidad no tenía el mismo significado que el conocimiento de los hechos característicos del dolo; mientras que en la teoría del dolo el conocimiento de la antijuridicidad tenía que ser un conocimiento actual (igual que el de los hechos), para la teoría de la culpabilidad el conocimiento de la antijuridicidad era más bien un conocimiento de tipo virtual: basta con que el sujeto hubiera podido conocer la antijuridicidad de su hecho. Para la teoría de la culpabilidad, si el desconocimiento de la antijuridicidad se debe a un error invencible, queda excluida la culpabilidad, pero si el error es vencible, la culpabilidad queda atenuada, subsistiendo la imputación dolosa (limitada al conocimiento y voluntad de los hechos), sin transformarse en imprudencia.

Detrás de estas elucubraciones dogmáticas, aparentemente sólo teóricas, había, sin embargo, un importante problema político-criminal que resolver: ¿hasta qué punto y dentro de qué límites había que darle relevancia al error de prohibición? Frente a la posición tradicional del Reichsgericht, de irrelevancia absoluta del error de derecho, por lo menos del error sobre las normas penales (otra cosa empezó a admitirse para el error de derecho extrapenal $^{64}$ ), la doctrina venía exigiendo, por razones estrictamente dogmáticas, en coherencia con el concepto de dolo o de culpabilidad que estaba desarrollando, el conocimiento de la antijuridicidad como presupuesto de la pena. El problema era, sin embargo, que si ese conocimiento se incluía en el concepto de dolo se le tenía que equiparar necesariamente con el conocimiento de los hechos, teniendo, por tanto, que ser un conocimiento actual, lo que planteaba especiales dificultades de prueba en el proceso penal y hacía surgir en la praxis el temor a su alegación frecuente por las defensas de los acusados. Mientras que si el conocimiento de la antijuridicidad se consideraba un elemento autónomo de la culpabilidad, independiente del concepto de dolo, era más susceptible de un tratamiento valorativo, lo que en la práctica equivaldría a que se considerara suficiente con su «cognoscibilidad», es decir, con la posibilidad de su conocimiento, sin requerir la

Merkel, Derecho penal, traducción del alemán de P. Dorado, Madrid s/f, págs. 98 y ss.). La idea fue desarrollada posteriormente por algunos autores en los años veinte (Sauer, Hirschberg, Paul Merkel, etc.), pero no tuvo acogida hasta después de 1945, gracias sobre todo a su acogida y desarrollo en la teoría final de la acción de Hans Welzel (de este autor vease, por ejemplo, El nuevo sistema de Derecho penal citado en nota 20, págs. 112 y ss.).

${ }^{64}$ Sobre la evolución del Reichsgericht en esta materia, véase el trabajo de Kühnl, Die Unterscheidung von vorsatzausschliessenden und nichtvorsatzausschliessenden Irrtum, 1987, págs. 361 y ss. Sobre la jurisprudencia del Reichsgericht hasta los años 30 informa Mezger, Tratado citado en nota 12, tomo II, pág. 159 y ss. Sobre la evolución posterior, Maurach, Tratado citado en nota 19, 11 , págs. 132 y ss. 
prueba del conocimiento mismo. A ello se añadía que la teoría del dolo, al transformar el error vencible en un delito culposo o imprudente, producía lagunas de punibilidad, ya que esta forma de imputación del delito sólo es punible, en un sistema de «numerus clausus», en algunos casos. Sin embargo, la teoría de la culpabilidad, al transformar el error vencible sobre la antijuricidad en una causa de atenuación del pena, deja subsistente la imputación por el delito doloso cometido. No es, por tanto, extraño que, mientras que en la doctrina fue dominante la teoría del dolo, la jurisprudencia no tuviera el menor interés en acoger sus $\operatorname{postulados}^{65}$; y que sólo a partir de la teoría de la culpabilidad, desarrollada sobre el concepto final de acción por Hans Welzel en los años 30, fuera acogida, primero en la Sentencia del Bundesgerichtshof de 18 de marzo de 1952, y, luego, introducida en el StGB en 1969, constituyendo el actual parágrafo 17, si bien con una atenuación meramente facultativa para el Tribunal en caso de error de prohibición vencible ${ }^{66}$. En el Código penal español, la regulación del problema en el párrafo 3 del artículo 6 bis a, tras la reforma de 1983, es muy similar a la alemana, si bien la atenuación en caso de error vencible es muy cualificada y obligatoria para el Tribunal que así lo aprecie ${ }^{67}$.

Sorprende, sin embargo, que un avance tan importante fuera más producto de discusiones doctrinales dogmáticas que de una decisión político-criminal consciente en favor de una democratización del Derecho penal, por la que se concedía una mayor relevancia a los «prejuicios jurídicos» del ciudadano frente al imponente poder punitivo del Estado ${ }^{68}$. Pero, como señala Achenbach, es muy característico de la Dogmática jurídico-penal de la República de Weimar prescindir de toda fundamentación de sus posiciones basándolas en la Revolución de 1918 o en la propia Constitución de 11 de agosto de 1919:

${ }^{65}$ Maurach, Tratado citado en nota 19, II, pág. 134.

${ }^{66}$ Dice el parágrafo 17 del actual Código penal alemán: «Si falta en el autor en el momento de la comisión del hecho el conocimiento de que está realizando un injusto, quedará exento de culpabilidad, si no podía evitar ese error. Si el autor podía evitar ese error, la pena puede ser atenuada conforme a lo dispuesto en el parágrafo 49, párrafo $1 .^{\circ} »$. Una disposición similar se recogía ya en el Proyecto de 1930. Sin embargo, el Proyecto de Radbruch en su pfo. 13 acogía la teoría del dolo.

${ }^{67}$ El pfo. 3 del art. 6 bis a) del Código penal español dice: «La creencia errónea e invencible de estar obrando lícitamente excluye la responsabilidad criminal. Si el error fuere vencible se observará lo dispuesto en el artículo 66», es decir, la atenuación muy cualificada, la rebaja de la pena prevista para el delito en uno o dos grados, que es el régimen penal que se sigue en caso de existencia de una eximente, causa de justificación o inculpabilidad, incompleta. Para más detalles, véase Muñoz Conde, El error en Derecho penal, Valencia, 1989.

${ }^{68}$ Así lo entiende Hassemer, Fundamentos del derecho penal, traducción de Arroyo Zapatero y Muñoz Conde, Barcelona, 1984, pág. 120. 
«El cambio de la situación del ciudadano individual en el Estado republicano democrático y la introducción de los derechos fundamentales no fueron concebidos como una llamada para revisar las concepciones tradicionales de la idea de culpabilidad y su acogida jurídica. Nunca se planteó que la pena como intervención en la libertad personal o en la propiedad y con ella la culpabilidad como uno de sus reguladores esenciales también tiene un aspecto jurídico-constitucional. La tradición filosófica de la Ciencia del Derecho penal había ya troquelado la relación de las teorías de la Parte General y especialmente la teoría de la culpabilidad del Código penal en la conciencia de la Ciencia del Derecho penal hasta el punto de quedar excluida completamente la vinculación de este complejo con las muchas veces poco querida Constitución republicana» ${ }^{69}$.

Ciertamente, la elaboración de conceptos dogmáticos trascendentes, plenos de contenido filosófico, más allá de los márgenes que permitían las normas legales positivas, podría entenderse como un abandono del positivismo jurídico, característico del período inmediatamente anterior a la República de Weimar ${ }^{70}$; pero, curiosamente, este abandono del positivismo podía tener también una lectura estrictamente política. Como dice Kühnl ${ }^{71}$ :

«Este tipo de teorías en las que las «normas de rango superior» pueden ser inferidas de la esencia del hombre, de la esencia de la comunidad o de la voluntad divina, son susceptibles de adaptarse a cualquier tipo de contenido. Por ejemplo, en la época de la Ilustración y de la revolución burguesa tenían un contenido de carácter progresista que hacía referencia a los derechos humanos universales frente al sistema absolutista imperante. Sin embargo, en la República de Weimar fueron elaboradas por la derecha para limitar la vigencia de las leyes aprobadas por el Parlamento y para, de este modo, librar en lo posible al poder ejecutivo del control democrático».

\footnotetext{
${ }^{69}$ Achenbach, ob. citada en nota 49, pág. 135.

${ }^{70}$ Véase mi Introducción citada en nota 4, pág. 104 y ss. También Lucas Verdú, La lucha contra el positivismo jurídico en la República de Weimar, Madrid, 1989.

${ }^{71}$ Kühnl, ob. citada en nota 41, pág. 141.
} 
Sería, sin duda, exagerado atribuir este significado político coyuntural al concepto de culpabilidad elaborado por la Dogmática jurídico-penal alemana en los años veinte, aunque no deja de ser paradójico que su rica elaboración prácticamente cesara con el advenimiento del régimen nazi ${ }^{72}$, dejando su lugar a otro tipo de elucubraciones más afines con el nuevo régimen político ${ }^{73}$.

En todo caso, no se puede discutir que el concepto de culpabilidad, en sus líneas básicas y al margen de cuál fuera su fundamentación filosófica o política, fue una de las conquistas más importantes de la Dogmática jurídico-penal alemana de aquella época. Entendido como garantía y límite frente al poder punitivo del Estado se le considera hoy como uno de los principios fundamentales de un Derecho penal democrático y respetuoso con la dignidad humana ${ }^{74}$. Pero un sistema estrictamente dualista, como el que se forjó en la República de Weimar, en el que la pena limitada por la culpabilidad puede ser sustituida o complementada por una medida de seguridad de duración indeterminada fundamentada en un concepto tan vago y peligroso corno el de peligrosidad, traduce una concepción del Derecho penal muy vinculada a las tesis amigo-enemigo tan caras al Estado nacionalsocialista ${ }^{75}$ : Un Derecho penal con todas sus garantías, basado y limitado por el principio de culpabilidad, para el delincuente ocasional, integrado en el sistema, aunque alguna vez se aparte de él; y un Derecho penal basado en la peligrosidad y sin ningún tipo de limitaciones, para el delincuente peligroso y especialmente para el delincuente habitual que con su comportamiento y su forma de conducción de vida (Lebensführungschuld) cuestiona las bases del sistema mismo.

Afortunadamente, este planteamiento dualista extremo va siendo poco a poco abandonado y sustituido por un sistema combinado de penas y medidas, en el que éstas pasan a ser limitadas, además de por el principio de proporcionalidad, por los mismos criterios de duración temporal que las penas, convirtiendo el límite máximo

\footnotetext{
${ }^{72}$ Véase Achenbach, ob. citada en nota 43, pág. 199, 203.

${ }^{73}$ Véase Schaffstein, «Rechtswidrigkeit und Schuld im neuen Strafrechtssystem», en Zeitschrift für die gesamte Strafrechtwissenschaft, 57, 1937. págs. 295 y ss.

${ }^{74}$ Aunque se discute todavía tanto su fundamento como su contenido, no cabe duda de que entendido como exclusión de la responsabilidad puramente objetiva, o como exigencia de participación o responsabilidad subjetiva, goza de reconocimiento más allá de los márgenes estrictamente dogmáticos; véase Muñoz Conde/García Arán, Derecho penal, citado en nota 5, págs. 87 y ss.

${ }^{75}$ Tesis defendida en varios trabajos por uno de los más destacados representantes de la Filosofía del Estado más afín al nacionalsocialismo, Carl Schmitt; véase Marxen, Der Kampf, citado en nota 41.
} 
de duración de las penas en el límite máximo de duración de la medida y computando el tiempo de duración de ésta en el de la pena, de la que incluso se puede prescindir si una vez cumplida la medida se ha conseguido eliminar la peligrosidad criminal que dio lugar a su aplicación (sistema vicarial) ${ }^{76}$.

Este sistema vicarial no acaba, sin embargo, de imponerse para los delincuentes habituales, para los que por ejemplo el StGB sigue previendo el internamiento en custodia de seguridad (parágrafo 66, modificado, en sentido restrictivo, a partir del 1 de enero de 1985) y con una duración de diez años en el primer internamiento, pero indefinida en los demás, limitando su aplicación, por lo demás bien escasa ${ }^{77}$, al delincuente «por tendencia» (Hangverbrecher), nuevo concepto que viene a sustituir el antiguo de reincidente o habitual.

En el Código penal español se sigue, en cambio, manteniendo la agravante de reincidencia (art. 10,15..$^{\mathrm{a}}$ ), a pesar de las reservas que se han formulado contra ella desde el punto de vista de su constitucionalidad ${ }^{78}$, y en algunos delitos (aborto, receptación) se le da un tratamiento específico al delincuente habitual, excluyéndose a los reincidentes del beneficio de la condena condicional (art. 93, 1), prolongando el art. 118, $4 .^{\circ}$ los plazos para la cancelación de antecedentes penales en los supuestos de reincidencia en un cincuenta por ciento. Pero desde el punto de vista de las medidas de seguridad, no se prevé ninguna reacción especial ni en el Código penal vigente, ni en el Proyecto de 1992 (1994), renunciándose a cualquier tipo de terapia social como proponía, en cambio, la Propuesta de Anteproyecto de 1983 (art. 100) ${ }^{79}$, y el antiguo parágrafo 65 StGB hasta que fue definitivamente derogado en $1985^{80}$.

La renuncia o supresión de la medida de internamiento en centro de terapia social demuestra el escepticismo con el que se miran hoy los programas de tratamiento, pero también las críticas realizadas

${ }^{76}$ Véase Muñoz Conde, Derecho penal y control social, Jerez, 1985, pág. 71 y ss. (hay versión parcial de esta obra al alemán, publicada en dos artículos: «Monismus und Dualismus im spanischen Strafrecht», en Goltdammers Archiv, 1984; y «Vorschlag eines neuen Massregelsystems», en Hassemer (edit.) Strafrechtspolitik, Frankfurt a. M., 1987).

${ }^{77}$ Sobre la actual regulación del internamiento de seguridad en el Derecho penal alemán, véase Jescheck, Lehrbuch des Strafrechts, 4. a ed., 1988, págs. 733 y ss. Según este autor, en 1967 todavía había unos 200 condenados a esta medida, en el año 1970 todavía 110, en 1985 sólo 39, y el número total de los sometidos a esta medida al 31-3-1986 era sólo de 24 (pág. 734).

78 Véase STC 150/1991, de 4 de julio. Al respecto, Zugaldía Espinar, «Sobre la inconstitucionalidad de la agravante de reincidencia», en Poder Judicial, 13, 1989.

${ }^{79}$ Véase Muñoz Conde, ob. citada en nota 76, pág. 79 y ss.

${ }^{80}$ Sobre su regulación hasta su derogación en 1985 informa Jescheck, Tratado citado en nota 1, pag. 1.123 . 
contra el concepto mismo de resocialización y la imposibilidad de su realización, cualquiera que sea el contenido que se le dé, en unas prisiones cada vez más hacinadas y en peor estado $^{81}$. Por otro lado, el reforzamiento de las garantías del ciudadano frente al poder punitivo del Estado, tanto en el ámbito de las penas como en el de las medidas, de lo que pueden ser una buena prueba los Proyectos españoles de 1992 y 1994, que siguen en esta materia la línea ya marcada por la Propuesta de $1983^{82}$, y la consecuente atenuación del contraste culpabilidad-peligrosidad ${ }^{83}$, que sirvió de base al sistema dualista puro ${ }^{84}$, han determinado un cambio de imagen del tradicional marco auspiciado por los Proyectos de Código penal de la República de Weimar y la reforma nacionalsocialista de 1933.

Afortunadamente, las actuales tendencias de la Ciencia alemana del Derecho penal procuran superar la perniciosa esquizofrenia metodológica en que incurrió durante el período de la República de Weimar, introduciendo la Política criminal en el tratamiento dogmático y sistemático de los problemas jurídico-penales ${ }^{85}$, u orientando

${ }^{81}$ Ya en 1979 me pronuncié contra una aceptación acrítica del concepto de resocialización y de las posibilidades de su consecución en los actuales establecimientos penitenciarios (véase Muñoz Conde, «La resocialización del delincuente, análisis y crítica de un mito», en Cuadernos de Política criminal, 1979, luego recogido, con algunas matizaciones ya hechas en posteriores trabajos sobre el tema, en Derecho penal y control social, citado en nota 76). Actualmente parece bastante extendido este escepticismo frente al concepto de resocialización, que por cierto tiene uno de sus orígenes en el Proyecto de Radbruch citado en nota 28, quien en la pág. 55 habla de una Ley penitenciaria basada en el sistema progresivo y en la idea de mejora (Besserung), que dio lugar a los Principios del Reichsrat de 1927 que hacía de la prevención de la reincidencia la meta principal del sistema penitenciario (parágrafo 48) y del sistema progresivo o gradual (parágrafos 130,131) un medio esencial para la realización de la idea de educación. Sobre el pensamiento de Radbruch en esta materia, véase la Introducción de E. Schmidt al Proyecto de Radbruch citado en nota 28, pág. XIII: «Las reservas que tiene el Proyecto de Radbruch en relación con la pena privativa de libertad, están dictadas por la idea de resocialización»».

${ }^{82}$ Véase Muñoz Conde, ob. citadas en nota 76.

${ }^{83}$ Véase Hassemer, Fundamentos citado en nota 68, pág. 298: «Ante la evolución alcanzada hoy en el sistema de ejecución de las penas y medidas, la gran tarea jurídico-constitucional y político-criminal no consiste en reactivar el contraste entre culpabilidad y peligrosidad, sino en el desarrollo de instrumentos que, por un lado, determinen que se imponga al delincuente una consecuencia jurídico-penal que sea una respuesta lo más precisa posible a su hecho y a su personalidad y que, por otro lado, garanticen que el delincuente, tanto en el ámbito de las medidas como en el de las penas, quede protegido en sus derechos ante intervenciones desproporcionadas. Ante esta tarea la distinción entre penas y medidas es de importancia secundaria».

${ }^{84}$ Véase, por ejemplo, Maurach, Tratado citado en nota 19, tomo I, págs. 58 y ss.

${ }^{85}$ Véase, por ejemplo, Roxin, Sistema del Derecho penal y política criminal, traducción e introducción de Muñoz Conde, Barcelona, 1972. 
el sistema penal out put, hacia las consecuencias preventivas que se pretenden alcanzar con é $1^{86}$. Naturalmente, tampoco estas tendencias están exentas de incurrir en exageraciones funcionalistas de las que ya hay más de un ejemplo en el momento presente ${ }^{87}$, justificando el Derecho penal por sus efectos, sin cuestionar el sistema social, político o económico que le sirve de base. Pero éste y otros riesgos semejantes no sólo acechan a la actividad jurídico-penal, sino a cualquier otra actividad intelectual, jurídica o extrajurídica. Pero si de algo se puede acusar globalmente a los penalistas alemanes de la época de la República de Weimar, valoraciones ideológicas aparte, es de haber sido demasiado consecuentes con los postulados puramente dogmáticos de los que partían, cultivando la Dogmática jurídico-penal l'art pour l'art, alejándose bastante de la realidad política, social y económica que les tocó vivir, y dejando, en cierto modo, con sus exquisiteces y elucubraciones teóricas, la puerta abierta a la terrible bestia del fascismo, al que no quisieron o no supieron ver como el verdadero enemigo de la dignidad humana.

Ojalá los tiempos hayan cambiado y los penalistas de ahora estemos más preparados, si no para evitar, sí, por lo menos, para identificar los verdaderos peligros que acechan a una configuración pacífica y democrática de la convivencia social, con la manipulación ilimitada del arma más terrible de que dispone el Ordenamiento jurídico estatal: el Derecho penal. Para que no pase lo que ya Gustav Radbruch denunció con especial clarividencia en 1926:

«Con demasiada frecuencia, tanto antes de la guerra, como durante ella, el profesor se había convertido en una especie de trompeta convencida de que era ella quien tocaba, ignorando que eran otros quienes soplaban... Con el caudillismo y su parafernalia, las Universidades fueron arrastradas por el espíritu de la época, pero con frecuencia fueron ellas quienes arrastraron a su vez al resto de la sociedad hacia aquel espíritu» ${ }^{88}$.

\footnotetext{
${ }^{86}$ Véase Hassemer, Fundamentos citado en nota 68, pág. 35; Hassemer/Muñoz Conde, Introducción a la Criminología y al Derecho penal, Valencia, 1989, págs. 15 y ss.

${ }^{87}$ En esta línea se mueve el Tratado de Jakobs, citado en nota 60, que está ejerciendo una gran influencia tanto en la Ciencia alemana como en la española del Derecho penal; véase, por ejemplo, Schünemann (comp.), El sistema moderno del Derecho penal: cuestiones fundamentales, introducción, traducción y notas de Silva Sánchez, 1984. Véase también, Silva Sánchez, Aproximación al Derecho penal contemporáneo, Barcelona, 1992, págs. 67 y ss. Críticamente: Muñoz Conde, Derecho penal, citado en nota 76, págs. 26 y 112 ss.

${ }^{88}$ Citado por Kühnl, ob. citada nota 41, pág. 148.
} 